\title{
Suomalaiset modernit tehtaat kansainvälistyvässä taloudessa
}

\author{
Raimo Lovio
}

Käsittelen meneillä̈̈n olevaa teollisuuden rakennemuutosta kahdesta näkökulmasta. Ensinnäkin kiinnitän huomiota nopeaan kansainvälistymiseen ja toiseksi pohdin teollisen toiminnan luonteen muutosta. Keskityn uusien rakenteiden muotoutumiseen ja jätän varsin vähälle huomiolle vanhojen rakenteiden murtumisesta aiheutuvat työllisyys- ja muut ongelmat. Sanalla moderni on tässä yhteydessä vain ajankulkuun viittaava merkitys.

\section{KANSAINVÄLISTYMISEN LÄPITUNKEVUUS}

Kilpailukyky, kilpailukyky, kilpailukyky. Miksi sitä hoetaan niin paljon ja miksi tuo hokema menee niin hyvin perille?

Paljolti siksi, että sillä kiertämättömästi on vankka perusta itse todellisuudessa: ulkomaankaupan merkitys kasvaa jatkuvasti, teknologinen yhteistyö yli rajojen lisääntyy ja yritykset kansainvälistyvät. Katsotaanpa hieman tuoreita tilastoja.

\section{Ulkomaankaupan kasvava merkitys}

Suomen taloutta on 1950-luvun puolivälistä lähtien avattu kansainväliselle kaupankäynnille. Tämän kehityksen myötä kotimarkkinoiden merkitys teollisuudelle on nopeasti supistunut ja vastaavasti tuontitavarat ovat vallanneet vankemman aseman Suomen markkinoilla.

Muutos näkyy selkeästi taulukon 1 luvuista. Viennin osuus Suomen teollisuuden tuotannosta

Taulukko 1. Viennin osuus teollisuustuotannosta ja tuonnin osuus teollisuustavaroiden kotimarkkinoista Suomessa, \%.

$\begin{array}{lllll} & 1959 & 1970 & 1980 & 1986 \\ \text { Viennin osuus } & 38,2 & 53,1 & 62,2 & 69,2 \\ \text { Tuonnin osuus } & 17,6 & 34,1 & 37,2 & 47,8\end{array}$

Lähde: laskettu Ahde ym. 1987, 33. on jo $70 \%$ ja tuonnin osuus teollisuustavaroiden lopputuotekysynnästä on jo lähes $50 \%$.

Luvut koskevat teollisuutta keskimäärin. Ei ole vaikeaa löytää toimialoja tai yrityksiä, joilla viennin osuus lähentelee tai jopa ylittää $90 \%$.

Ulkomaankaupan kautta Suomi on tiukasti sidottu OECD-maiden talouteen. Vuonna 198776 $\%$ tuonnista tuli näistä maista ja vastaavasti $74 \%$ viennistä meni näihin maihin. Pohjoismaiden osuus Suomen viennistä oli vuonna $198724 \%$ (Ruotsin osuus oli yksin $15 \%$ ) ja SEV-Euroopan $17 \%$ (Neuvostoliiton osuus yksin $15 \%$ ). Suomen teollisuudelle Pohjoismaiden ja Neuvostoliiton "laajennetut kotimarkkinat" ovat siis edelleen tärkeät.

Suomen teollisuuden asemaa kansainvälisessä työnjaossa voi lyhyesti luonnehtia siten, että Suomi on OECD-alueen kärkimaiden perässä hiihtävä maa, joka kuroo etumatkaa umpeen tuomalla uutta teknologiaa kärkimaista, soveltamalla sitä nopeasti omille vahvoille aloille ja viemällä näin kehitettyjä tuotteita aluksi lähimarkkinoille ja myöhemmin laajemmallekin (ks. Lovio \& Lemola 1986).

Viime vuosina kauppavaihto on sujunut hyvin. 10-vuotiskaudella 1977-86 kauppatase oli positiivinen (juoksevin hinnoin kumulatiivinen ylijäämä oli 6031 Mmk). Ja viime vuonnakin ylijäämää kertyi 895 Mmk. Kilpailukykyä on siis ollut lisääntyvän kaupallisen integraation oloissa.

\section{Tiivistyvä teknologinen yhteistyö}

Ulkomaankaupan lisääntymisen myötä moni muukin yhteistyö lisääntyy. Viime vuosina erityisen paljon on tapahtunut teknologisen yhteistyön alueella. Päätapahtumat on kirjattu taulukkoon 2. Tarkastelu on rajattu Länsi-Euroopan teknologiseen integraatioon. 
Taulukko 2. Suomen ja Länsi-Euroopan teknologiayhteistyön voimistuminen.

\section{EUREKA (alk. 1985)}

— Suomalaiset yritykset ja tutkimuslaitokset mukana 18 projektissa 165 projektista

\section{EY:n TUTKIMUSOHJELMAT}

— Suomen ja EY:n välille puitesopimus 1986

— Eräät tutkimuslaitokset ja yritykset jo mukana joissakin ohjelmissa:

— tietoliikenneohjelma RACE: 9 projektia

— perusteollisuuden ohjelma BRITE: 2 projektia

- materiaalitekniikan ohjelma: 5 projektia

— puuohjelma: 5 projektia

— informaatioteknologian ohjelma ESPRIT: projekteja valmistelussa

\section{EUROOPAN AVARUUSJÄRJESTÖ ESA}

— vuoden 1987 alusta Suomi liitännäisjäseneksi

— osallistutaan tiede- ja kaukokartoitusohjelmaan

\section{HIUKKASFYSIIKAN TUTKIMUSKESKUS CERN}

— erillissopimuksen muuttamisesta jäsenyydeksi keskustellaan

— pieniä vastaavia ovat Euroopan molekyylibiologian tutkimuslaboratorio EMBL (Suomi jäsen) ja eurooppalainen säteilysynkrotroni ESR (jäsenyys valmisteilla)

COST (European Cooperation in the Field of Scientific and Technical Research)

— osallistuttu vuodesta 1971 yli 20 hankkeeseen

Julkisuudessa uusista yhteistyömuodoista eniten huomiota on saanut Ranskan aloitteesta syntynyt Eureka-yhteistyö, josta Suomen teollisuus aluksi aiottiin jättää syrjään.

Ehkäpä tästä loukkaantuneena Teknologian Kehittämiskeskus TEKES ja monet teollisuusyritykset ovat olleet hyvin aktiivisia Eureka-projektien aikaansaamisessa. Viime vuoden lopulla suomalaisia oli mukana käynnistyneestä 165 projektista 18 projektissa (Kuusi, J. 1987a, 9).

Eureka-yhteistyötä tärkeämmäksi lähitulevaisuudessa muodostuu Suomen tutkimuslaitosten ja yritysten osallistuminen EY:n mittaviin tutkimusohjelmiin. Suomi allekirjoitti vuonna 1986 muiden EFTA-maiden tapaan EY:n kanssa puitesopimuksen, joka mahdollistaa suomalaisten osallistumisen näihin ohjelmiin. Tällä hetkellä suomalaiset ovat osallisena jo yli 20 projektissa.

Eniten projekteja on tietoliikenneohjelma RACE:ssa. Tulevaisuudessa eniten projekteja lienee informaatioteknologian tutkimusohjelmassa ESPRIT:ssä, joka on EY:n tutkimusohjelmista selvästi suurin.

Ylipäänsä informaatioteknologia dominoi jos mahdollista entistäkin selvemmin - teknologiaohjelmia niin kansainvälisellä kuin kansallisellakin tasolla. Noin puolet teknologiaohjelmien määrärahoista niin EY:ssä, Eurekassa kuin Suomessakin suuntautuu informaatioteknologian alalle (Kuusi, J. 1987b, 30). Uuden pitkän aallon teknologista paradigmaa ajetaan siis väellä ja voimalla läpi.

Suomalaisten tutkimuslaitosten ja yritysten muutamassa vuodessa tekemät osallistumispäätökset alkavat olla rahallisesti jo varsin huomattavia. Huomattava osa Suomessa tehtävästä luonnontieteellis-teknisestä soveltavasta tutkimuksesta on muuttumassa kansainvälisen yhteistyön kautta ohjautuvaksi. Ei ihme, että CERN-jäsenyyden tarpeellisuudesta väitellään: resurssien niukkuus pakottaa punnitsemaan hankkeita keskenään.

\section{Yritysten kansainvälistyminen}

Selvin uusi piirre Suomen teollisuuden kansainvälistymisessä 1980-luvulla on ollut yritysostoin toteutettava tuotantolaitosten hankkiminen ulkomailta. Taustalla on perustrategian muutos suuryrityksissä. Kun aikaisemmin yritykset diversifioituivat kotimarkkinoiden pohjalla, niin nyt pyrkimyksenä on keskittyminen ja kansainvälistyminen vahvoilla aloilla. Tosin diversifioitumisen purkaminen on ainakin tähän saakka ollut suhteellisen vähäistä (Räsänen 1988). 
Kansainvälistymisen tuloksia ovat ETLA:n (Ahde ym. 1987, 39) tutkijat tiivistäneet näin:

\begin{abstract}
"Suomalaisomisteisten ulkomaisten yritysten lukumäärä kasvoi vuodesta 1980 vuoteen 1986 lähes kaksinkertaiseksi ja teollisuuden ulkomaisten suorien sijoitusten määrä yli kolminkertaiseksi. Ulkomaille suuntautuvien investointien osuus teollisuuden kotimaisesta pääomanmuodostuksesta on nykyään vajaat $10 \%$... Suomalaisten yritysten kaikista suorista sijoituksista 1980-luvulla noin kolmannes on suuntautunut muihin Pohjoismaihin, viime vuonna osuus oli yli $50 \%$... Suomen teollisuuden rakennemuutoksella onkin kiinteä yhteys koko Pohjolan alueella meneillään olevaan rakennekehitykseen.”
\end{abstract}

1980-luvun alussa suomalaisista teollisuusyrityksistä vain 3 oli edennyt monikansalliseen vaiheeseen (tuotantolaitoksia vähintään kuudessa

Taulukko 3. Suomalaisten teollisuusyritysten ulkomaiset tuotannolliset tytäryhtiöt ja niiden henkilökunta, helmikuu 1988.

\begin{tabular}{lcc} 
Emoyhtiö & $\begin{array}{c}\text { Tytäryrit. } \\
\text { lukumäärä }\end{array}$ & $\begin{array}{l}\text { Henkilö- } \\
\text { kunta }\end{array}$ \\
\hline Nokia & 20 & 21000 \\
Kone & 18 & 13000 \\
Valmet & 16 & 6200 \\
Outokumpu & 11 & 5800 \\
Kemira & 11 & 5600 \\
& 12 & 5600 \\
Partek & 7 & 4000 \\
Huhtamäki & 13 & 3700 \\
Neste & 12 & 3200 \\
Wärtsilä & 16 & 2300 \\
Rauma-Repola & & 2200 \\
Kymmene & 4 & 2000 \\
Ahlström & 10 & 1800 \\
Metsä-Serla & 8 & 1500 \\
Fiskars & 8 & 1400 \\
Asko & 14 & 11000 \\
Muut & 87 & -10300 \\
\hline Yhteensä & -161 &
\end{tabular}

Lähde: laskettu Talouselämä-lehden (25/87, 1/88, 4/88) tiedoista. maassa) (Luostarinen 1980). Nyt tämän kriteerin mukaan monikansallisia yrityksiä on jo yli 10 , kuten ilmenee taulukosta 3.

Kaikkein hurjimmin aivan viime aikoina on kansainvälistynyt Nokia, joka elektroniikkateollisuutensa kasvattamiseksi on perustanut yhteisyrityksiä (esim. radiopuhelintehdas Etelä-Koreaan), ostanut ulkomaisia yrityksiä (esim. Luxor Ab, Oseanic S.A., SEL AG ja LME:n tietokonealan liiketoiminta) ja muodostanut yhteistyökonsortioita (esim. digitaalisen matkapuhelinverkon kehityssopimus Alcatelin ja AEG:n kanssa). Nykyisin Nokia on mm. Euroopan kolmanneksi suurin väritelevisioiden valmistaja, seitsemänneksi suurin tietokonealan yritys ja kilpailee suurimman radiopuhelinvalmistajan paikasta.

Näiden operaatioiden ja sisäisen kasvun seurauksena Nokian elektroniikan henkilökunta on vuodesta 1978 vuoteen 1988 kasvanut 2000 henkilöstä 28000 henkilöön! Nokian henkilökunnan kokonaismäärä on tällä hetkellä noin 44000 , josta ulkomailla on 21000 . Kun lisäksi Nokian operatiivista päätöksentekoa ollaan siirtämässä kulutuselektroniikassa Saksan liittotasavaltaan, informaatiojärjestelmissä Ruotsiin, kaapelikoneissa Sveitsiin ..., voidaan sanoa, että Nokiasta on kehittymässä Suomen teollisuushistorian ensimmäinen suuri monikansallinen yritys.

Samaan aikaan kun suomalaiset yritykset ovat ostaneet itseään maailmankartalle, on myös suomalaisia yrityksiä siirtynyt ulkomaiseen omistukseen — tosin huomattavasti vähäisemmässä määrin. Suomessa ei käydä huolestunutta keskustelua kansallisen teollisuuden säilymisestä, toisin kuin esimerkiksi Tanskassa ja Belgiassa.

Strömbergin siirtyminen osaksi jättiläismäistä ASEA Brown Boweria oli kuitenkin varsin merkillepantava tapahtuma. Ja itse asiassa Strömbergin tapaus kuvastaa varsin hyvin meneillään olevan kansainvälistymisen logiikkaa: samalla kun lähes 7000 työntekijän Strömberg liitettiin ABB:hen, osasta Strömbergiä muodostettiin erillinen yksikkö Strömberg Drives, joka sai ABB:n 
piirissä maailmanlaajuisen vastuun omalla alueellaan ja samalla johdettavakseen lähes 7000 työntekijää eri puolilla maailmaa. Näin valtaosaa suomalaisia strömbergiläisiä johdetaan ulkomailta, samalla kun osa suomalaisista johtaa pientä osaa ABB:n yli 150000 työntekijästä eri puolilla maailmaa.

\section{Miten suhtautua kansainvälistymiskehitykseen?}

Edellä esitetyn sanoma on yksinkertainen: Suomen teollisuus ja teknologinen kehitystyö on kansainvälistymässä jopa hämmästyttävällä nopeudella. Kysymys siitä minkälaisia seurauksia sillä on Suomen talouteen ja miten siihen tulisi ylipäätään suhtautua on todella sananmukaisesti ensiluokan kysymys.

Erik Allardt $(1987,251)$ on todennut:

\begin{abstract}
"Vad som är nytt i den nuvarande debatten är snarast att många frontlinjer ifråga om inställningen till värdsamhället har förändrats. Traditionellt har det varit vänstern och intellektuella som betonat internationalisering som ett uttryck för internationell solidaritet. I dag är det ofta affärslivets representanter som talar för internationaliseringen."
\end{abstract}

Ja todellakin: mitä vihreämmälle tai vasemmalle tullaan, sitä äänekkäämmin kansainvälistyminen yleensä tai ainakin sen nykyiset ilmenemismuodot tuomitaan. Kun taas moittivan, olavipaavolaismaisen toteamuksen "suomalaisten henkinen eurooppalaistuminen ei ole vielä oikein alkanutkaan" lausuu pääohtaja Kari Kairamo (Uusi elektroniikka 29.2.1988).

Itse en ainakaan tällä hetkellä kykene näkemään mitään vaihtoehtoa kansainvälistymiselle, näen sen jopa monessa mielessä positiivisena ilmiönä. Kysymys on vain siitä missä muodossa ja kenen ehdoilla kansainvälistyminen tapahtuu ja Eurooppa integroituu. Kiukuttelu todellisuudelle ei auta.

Erilaiset yhteiskunnalliset liikkeet ovat jopa hämmästyttävässä määrin jäljessä talouden ja yritysten kansainvälistymisestä. Kysymys on vakavasta rakenteellisesta heikkoudesta, jonka poistamisessa konkreettisen kansainvälisen yhteistyön kehittäminen kaikilla tasoilla näyttää ainoalta järkevältä vaihtoehdolta.

\section{TEOLLISEN TOIMINNAN MUUTOS}

\section{Intensiivinen kasvu}

Teollisuuden siirtyminen työvoiman käytön osalta ekstensiivisestä intensiiviseen kasvuun ja tähän liittyvä teollisuuden työvoiman määrän kääntyminen laskuun on jo hyvin tiedostettu ilmiö. Yhtä hyvin ei kuitenkaan liene tiedostettu tapahtuneen muutoksen voimakkuus.

Ennustin Tiede \& Edistyksessä (1/85) kolme vuotta sitten, että "tuskin on odotettavissa mitään rajua putoamista, mutta varsin perustellulta vaikuttaa ennuste, että 1990-luvun alussa on Suomen teollisuudessa henkilökuntaa noin 30000 vähemmän kuin tällä hetkellä̉'. Ennustamani jakson ensimmäisenä vuotena (vuodesta 1985 vuoteen 1986) vähennys oli teollisuustilaston mukaan jo 17000 , joten ennuste tulee osoittautumaan vääräksi. Vähennys on paljon rajumpaa, varmaankin yli 80000 henkilöä.

Kuvassa 1 on esitetty Suomen teollisuuden tuotannon ja työvoiman kehitys vuosina 1980 86 (teollisuustilaston mukaan). Tuotanto on kasvanut $16,5 \%$, toimihenkilöiden määrä $2,7 \%$ (3 500 henkilöä), mutta työntekijöiden määrä on vähentynyt peräti 14,3\% (61 400 henkilöä). Toimihenkilöidenkin määrä on kääntynyt laskuun tarkastelujakson viimeisenä vuonna.

Toimialoittain tarkasteltuna vain kolmella alalla - instrumenttien valmistus, muovituotteiden valmistus sekä graafinen teollisuus/kustannustoiminta - työntekijöiden määrä on kasvanut vuodesta 1980 vuoteen 1986. Enemmistöllä aloista myös toimihenkilöiden määrä on tällä hetkellä vähäisempi kuin vuonna 1980 . Määrällisesti rajuimmat työvoimasupistukset ovat tapahtuneet 


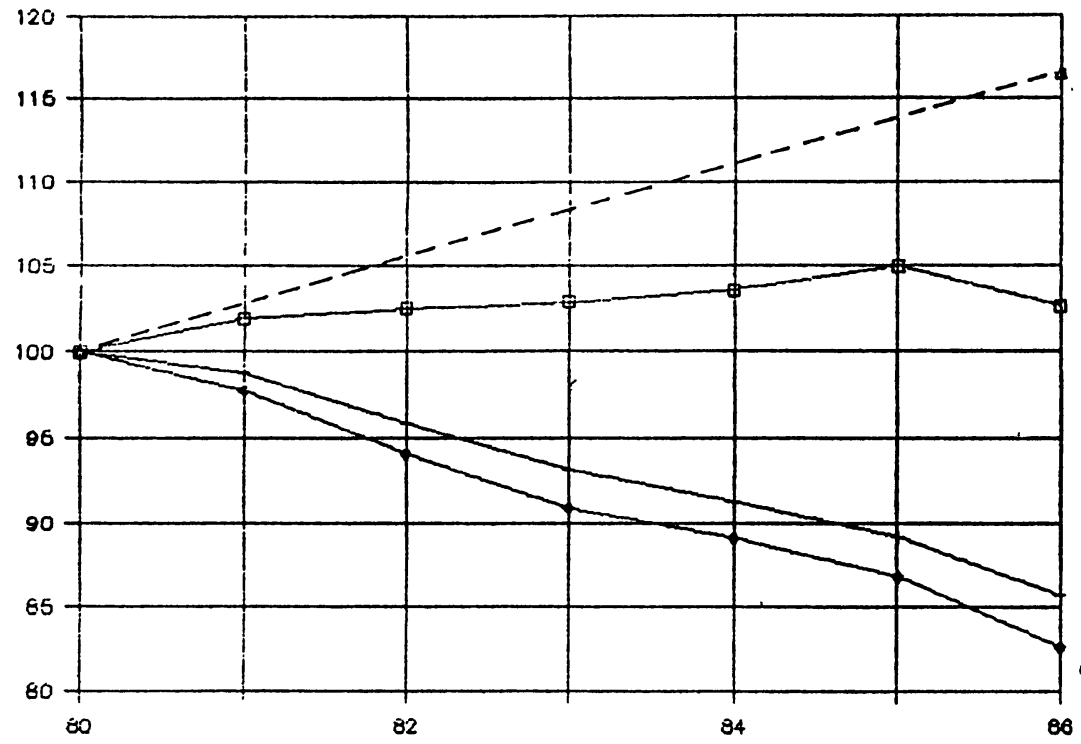

TUOTANTO

TOIMIHENK ILÖT

TYÖNTEKIJÄT

TYÖNTEK IJÖIDEN TYÖTUNNIT

Kuva 1. Suomen teollisuuden tuotannon ja työvoiman kehitys $1980-86,1980=100$.

Lähde: Teollisuustilasto.

metsä- ja ns. tevanake-teollisuudessa.

Teollisuus tuottaa siis nykyisin entistä enemmän tavaraa entistä vähemmällä työvoimalla (kuten maatalous on tehnyt jo pitkään). Teollisuuden työvoimatarpeen väheneminen palautuu ensinnäkin tuotannon kasvun hidastumiseen, joka johtuu kysynnän kasvun hidastumisesta ja työvoimavaltaisen teollisuuden osittaisesta siirtymisestä eräisiin kehitysmaihin. Toiseksi teollisuudessa automaatio etenee edelleen ja on parhaillaan tulossa erityisesti ns. kappaletavarateollisuuteen erilaisina joustavina tuotantoautomaatioratkaisuina (Vuorinen 1987). Ja kolmanneksi osa teollisuuden sisäisistä palveluista itsenäistyy erilliseksi yrityspalvelutoiminnaksi, jonka työvoimaa ei tilastoida teollisuuteen.

\section{Massatuotteista asiakastuotteisiin}

Teollisuuden tuoterakenteen muutosta on perinteisesti tarkasteltu toimialajakauman muutosten avulla. Enemmän muutoksia tapahtuu kuitenkin toimialojen sisällä. Perussuuntaus on siirtyminen entistä pidemmälle jalostettujen tuotteiden valmistukseen, mikä merkitsee samalla siirtymistä massatuotteista erikoistuotteisiin. Lisäksi entistä suurempi osa erikoistuotteista pyritään joustavasti valmistamaan kulloisenkin asiakkaan tilaamien erityisvaatimusten mukaisesti.

Siirtyminen asiakastuotteiden valmistukseen merkitsee laadullista muutosta koko teollisen toiminnan logiikassa. Kun massatuotteiden valmistuksessa toiminnan ydin on tuotannossa: tava- 
ra ensin tuotetaan, varastoidaan, kuljetetaan ja sitten myydään (jos myydään), niin asiakastuote ensin myydään ja suunnitellaan asiakkaan kanssa ja vasta sitten valmistetaan. Näin yhä useampi tehdas toimii kirjapainon tavoin: valmistus tapahtuu asiakkaiden tilausten perusteella.

\section{Teollisuus tieteellistyy — tiede teollistuu}

Myydyt tuotteet on kuitenkin ennen valmistusta kehitettävä. Toimialarakenteen muutos, jalostusasteen kohoaminen ja asiakaskohtaisten tuotteiden valmistus työntävät teollisuuden tutkimus- ja kehitystoimintaa vauhdilla eteenpäin.

Tutkimuksen tarve ja määrä vaihtelevat selvästi alasta ja yrityksestä toiseen. Elektroniikka-

Taulukko 4. Suomalaiset teollisuusyritykset, joilla oli suurimmat T\&K -menot 1987, sekä eräiden julkisten organisaatioiden tutkimusrahoitus.

\begin{tabular}{|c|c|c|}
\hline Yritys & $\begin{array}{l}\text { T\&K -menot } \\
\text { milj. mk }\end{array}$ & Toimiala \\
\hline Nokia & 582 & Moniala \\
\hline Neste & 366 & Kemia \\
\hline Valmet & 250 & Metalli \\
\hline Wärtsilä & (1986) & Metalli \\
\hline Kemira & 176 & Kemia \\
\hline Kone & 115 & Metalli \\
\hline Partek & 115 & Moniala \\
\hline Outokumpu & 115 & Metalli \\
\hline IVO & 102 & Sähkö \\
\hline Orion & 95 & Moniala \\
\hline
\end{tabular}

20 suurinta yhteensä 2728

Julkiset organisaatiot

$\begin{array}{lrl}\text { TEKES } & 401 & \text { t\&k -rahoitus } \\ \text { SITRA } & 61 & \text { kok.rahoitus } \\ \text { Suomen Akatemia } & 242 & \text { tutkimusrahoitus } \\ \text { VTT } & & \\ \begin{array}{l}\text { KORKEAKOULU- } \\ \text { MENOT }\end{array} & 545 & \text { kok.menot-tal.rak.inv. } \\ & 2574 & \text { kok.menot }\end{array}$

Lähde: Talouselämä 1/1988 ja vuosikertomukset. teollisuus käyttää tutkimukseen keskimäärin 15 $\%$ liikevaihdosta, mutta metsäteollisuus vain 1 $\%$ :n. Suurten suomalaisten monialayritysten tutkimustoiminta on kuitenkin jo saavuttanut huomattavat mittasuhteet, kuten näkyy taulukosta 4. Taulukko konkretisoi sitä yleisesti tiedettyä tosiasiaa, että yrityssektorin osuus kaikista tutkimusmenoista Suomessa on nykyisin $62 \%$. Se osoittaa, että 20 eniten tutkimusta harjoittavaa teollisuusyritystä käyttää nykyisin tutkimus- ja kehitystoimintaan enemmän rahaa kuin ovat Suomen korkeakoululaitoksen kokonaismenot, että Valmetin tutkimusbudjetti on suurempi kuin Suomen Akatemian ja että Nokia ei ole vain Suomen suurin teollisuusyritys vaan myös Suomen suurin tutkimuslaitos. Muutama elektroniikkateollisuutta koskeva esimerkki konkretisoi ehkä vielä enemmän kuvaa. Suomen teollisuushistorian suurimmassa tuotekehitysprojektissa, Telenokian digitaalisen puhelinkeskuksen kehittämisprojektissa tehtiin noin 10 vuoden aikana 2000 henkilötyövuotta. Nokian MikroMikkojen, Mobiran radiopuhelimien ja Valmetin Damatic-automaatiojärjestelmän kehittämiseen on kuhunkin osallistunut viime vuosina noin 300 henkilöä (ks. Lovio 1988).

Suurten elektroniikkayritysten tutkimuskeskukset eivät Suomessakaan ole enää mitään studioita, ne ovat pikemminkin tietotehtaita, joissa insinööritasoinen henkilöstö kehittää huomisen päivän työvälineitä eli ohjelmistoja.

\section{Kehittävien toimihenkilöiden esiinmarssi}

Työvoimarakenteessa edellä kuvatut trendit merkitsevät teollisuuden toimihenkilöistymisen etenemistä. Vuonna 1986 toimihenkilöiden osuus teollisuuden työvoimasta Suomessa oli teollisuustilaston mukaan jo $28 \%$. Kymmenellä toimialalla osuus oli yli kolmannes ja kahdella toimialalla yli puolet.

Toimihenkilöiden osuus on suuri pisimmälle automatisoidussa prosessiteollisuudessa (useilla 
kemian- ja elintarviketeollisuuden aloilla) sekä korkean jalostusasteen tuotteiden valmistuksessa (lääkkeiden, instrumenttien ja sähköteknisten tuotteiden valmistus).

Teollisuuden toimihenkilöistyessä työntekijöiden ja toimihenkilöiden välinen raja hämärtyy. Todellisuudessa maailma ei ole niin dikotominen kuin Tilastokeskus, työnantajat ja eri ammattiryhmät antavat meidän ymmärtää olevan. Rajan hämärtymistä tapahtuu ainakin kahdessa suhteessa.

Toisaalta valmistustyöntekijöiden kärjen (esim. ohjelmoitavia työstökoneita käyttävät työntekijät) työ alkaa muistuttaa perinteistä toimihenkilötyötä, jolloin syntyy myös keskustelua töiden jakamisesta ja ylipäätään toimihenkilöiden ja työntekijöiden välisestä tiukasta "säätyrajasta" (Kortteinen 1987, Kevätsalo 1987). Toisaalta ainakin suurissa elektroniikkayrityksissä ohjelmisto- tai kehitystyötä tekevästä insinööristä alkaa tulla normaali (keskimääräinen, tavanomainen) työntekijä tai ainakin normaalin työn tekijä.

Lisäksi toimihenkilökunnan — ja ehkä laajemminkin keskiluokkien ytimen (Kivinen 1987) sisällä määräsuhteet muuttuvat. Perinteisesti valtaosa teollisuuden toimihenkilöistä on työskennellyt taloudellis-hallinnollisten rutiinien pyörittämisessä (paperisota) ja työnjohdollisissa (valta) tehtävissä. Tällä hetkellä nopeimmin kasvavat erilaiset kehittävät toimihenkilötyöt (tuotteiden, prosessien, informaatiojärjestelmien ja markkinoinnin suunnittelijat, muotoilijat, kouluttajat jne.).

Näitä uusien prototyyppien tekijöitä (Virtanen 1987) tai osaavia tietoammattilaisia (Kuusi 1986) voisi kutsua kultakaulustyöntekijöiksi. Ei siinä mielessä, että he ansaitsisivat tällä hetkellä enemmän kuin valtaakäyttävät tai papereitapyörittävät toimihenkilöt; useimmiten asia lienee ainakin vielä päinvastoin. Mutta työnantajilleen he voivat olla kultakaivoksia. Nokian Informaatiojärjestelmien (nykyisin Nokia Data) johtaja Kalle Isokal- lio (Aivojen miljöö ... 1987) ilmaisee eräässä haastattelussa asian näin:

\begin{abstract}
"Nokia Informaatiojärjestelmät on postmoderni teollisuusyritys, jossa suhteet ovat toiset kuin yleensä teollisuudessa. Täällä 20 prosenttia ihmisistä on materiaaliläheisessä työssä ja 80 prosenttia aivointensiivisessä työssä. ... Fyysisessä työssä huono mies saa aikaan yhden yksikön, hyvä mies kaksi yksikköä. 'Aivointensiivisessä duunissa' huonosti motivoitunut tekee yhden yksikön ja hyvin motivoitunut sata yksikköä. Ero on yhtä huikea kuin Möttösellä ja Mozartilla sävellystyössä. ... Bisneksessä käytetään vastuualuejohtamista. Johtajat tietävät, mitä tavoitellaan. He varmistavat, että runsaat 3000 motivoitunutta ihmistä eivät mene väärään suuntaan. ... Pyrin siihen, että ammattilaiset voivat täällä motivoitua paremmin ja oppia enemmän kuin muualla. ... Yhtiö on aivojensa summa."
\end{abstract}

Motivoiminen (ulkoisen kontrollin asemasta) ja kouluttaminen (pelkän työssä perehtymisen asemasta) lienevätkin vähitellen nousussa juhlapuheiden lisäksi myös modernien teollisuusyritysten työnjohdollisissa käytännöissä, hitaasti varsinaisilla tehdassaleilla, mutta ehkäpä nopeammin kehitys-, suunnittelu- ja markkinointiosastoilla (työorganisaatioiden kehitystä ovat käsitelleet mm. Julkunen 1987 ja Toikka ym. 1985).

Joka tapauksessa teollisuusyritysten henkilöstön keskimääräinen koulutustaso (joka on tietysti hieman eri asia kuin varsinaisissa työtehtävissä päivittäin vaadittava tietotaito) on nousussa. Samalla julkisten koulutuslaitosten rinnalle on muodostumassa aika huomattavat menestyvien suuryritysten koulutusjärjestelmät ja -yksiköt, joita perustetaan myös yhteistyössä korkeakoulujen kanssa.

\section{Modernin teollisuusyrityksen anatomia}

Edellä kuvatun kehityksen seurauksena modernin teollisuusyrityksen toimintojen rakenne poikkeaa olennaisella tavalla perinteisen tehtaan, jonka varjossa tai valossa on eletty, toimintojen rakenteesta. Vanhanaikainen rautalankakuvio auttaa ehkä havainnollistamaan näitä erojá (kuva 2). 
LIIKKEENJOHTO (konsernin strategia, kansainväliset operaatiot)

INEORMAATIOJÄRJESTELMÄT (kaikki toiminnot kattava järjestelmä, cIM)

\begin{tabular}{|c|c|c|}
\hline \multicolumn{2}{|c|}{ HENKILÖSTÖN KOULUTUS } & $\begin{array}{l}\text { TALOUS } \\
\text { osa voidaan ostaa ulkoa }\end{array}$ \\
\hline MARKK INOINTI & TUOTEKEHITYS & $\begin{array}{l}\text { TUOTANTO = myytyjen ja kehitettyjen } \\
\text { tuotteiden valmistus }\end{array}$ \\
\hline $\begin{array}{l}\text { tarjoustoim. } \\
\text { ja muu tuot- } \\
\text { teiden etukä- } \\
\text { teismyyntı }\end{array}$ & $\begin{array}{l}\text { perustutkimus } \\
\text { yhteistyössä } \\
\text { julkisten tut- } \\
\text { kimuslaitosten } \\
\text { kanssa }\end{array}$ & $\begin{array}{l}\text { valmistuksen suunnittelu ja ohjaus } \\
\text { materiaalivirtojen logistiikka, JOT }\end{array}$ \\
\hline \multirow[t]{2}{*}{$\begin{array}{l}\text { perinteinen } \\
\text { mainonta } \\
\text { (voidaan } \\
\text { ostaa ulkoa) }\end{array}$} & $\begin{array}{l}\text { kehitystyö, } \\
\text { josta osa } \\
\text { voidaan ostada } \\
\text { ulkoa }\end{array}$ & $\begin{array}{l}\text { tuotteiden } \\
\text { ohjelmistojen } \\
\text { tojen ja muun } \\
\text { softwaren val- valmistus ja kokoon- } \\
\text { mistus pano osin alihankin- } \\
\quad \text { sekä asiakaskohtainen räätälöinti }\end{array}$ \\
\hline & $\begin{array}{l}\text { mallimuuntelu } \\
\text { design }\end{array}$ & korjaus ja huolto (osin ostetaan ulkoa) \\
\hline
\end{tabular}

Kuva 2. Modernin teollisuusyrityksen toimintojen rakenne.

Kuvassa 2 on erotettu kehittävien (prototyyppejä luovien) toimintojen alue (tuotekehitys, markkinointi - ainakin osin, ja koulutus; myös osan informaatiojärjestelmistä voisi laskea tähän) omaksi kokonaisuudeksi toteuttavien (monistavien) toimintojen (tuotanto, talous ja hallinto) rinnalle (vrt. Virtanen 1987). Selvää toki on, että kehittävää työtä tehdään jossain määrin myös tuotannossa ja hallinnossa.

Ensinnäkin kehittävien toimintojen suhteellinen merkitys on kasvanut. Tätä väitettä tukevat Tilastokeskuksen ja Talouselämä-lehden uusim- mat investointiselvitykset. Nykyisinhän tutkimus-, markkinointi- ja koulutusinvestointeja on alettu kutsua yhteisellä nimellä pehmoinvestoinneiksi tai aineettomiksi investoinneiksi. Tilastokeskuksen tekemän koekyselyn mukaan vuonna 1985 tehdasteollisuuden investoinneista aineellisten investointien (koneet ja rakennukset) osuus oli $68 \%$ ja pehmoinvestointien osuus $32 \%$ (tutkimus $16 \%$, koulutus $9 \%$ ja markkinointi $7 \%$ ) (Teollisuuden Keskusliitto 1987, 19-20). Talouselämä-lehden kyselystä voidaan laskea, että ainakin 10 suuryrityksessä pehmoinvestointien 
osuus oli yli $30 \%$ kokonaisinvestoinneista vuosina 1986-87 (Talouselämä 1/1988).

Toiseksi tuotannolla on markkinointiin ja tuotekehitykseen nähden strategisesti entistä vähäisempi merkitys. Tuotanto on myytyjen ja kehitettyjen tuotteiden valmistamista, entistä enemmän alihankintatoiminnan luonteista.

Kolmanneksi perinteinen tehdas oli ennen kaikkea fyysisten tavaroiden tuotantolaitos. Modernissa teollisuudessa fyysinen valmistus on entistä enemmän modulien, jotka voidaan ostaa alihankkijoilta, kokoonpanoa. Ja vaikeaa ei ole tämä laitteiden kokoonpano, vaan laitteita ohjaavien (usein asiakaskohtaisten) ohjelmistojen tekeminen. Entistä useammat koneiden ja laitteiden valmistajat ovatkin itse asiassa ohjelmistotaloja, jotka tosin myyvät tuotteensa fyysisiin laitteisiin sulautettuina.

Neljänneksi: modernit teollisuusyritykset ovat pyrkineet pääsemään kokonaan eroon vanhoihin tehtaisiin liittyneistä infrastruktuuripalveluista (työvoiman asunto- ja terveyspalvelut on siirretty valtiolle, työpaikkaruokalat erilaisille pitopalveluille, kiinteistönhoito isännöitsijätoimistoille, vartiointi vartiointiliikkeille, siivous servisystemsseille jne.). Siten modernien teollisuusyritysten paikallinen sidos ympäröivään yhteiskuntaan on vanhoja tehtaita huomattavasti vähäisempi tai ainakin välillisempi (Koistinen 1988).

Viidenneksi: teollisuusyritysten tehtaat on 1970-luvun puolivälistä lähtien nopeaan tahtiin muutettu suhteellisen itsenäisiksi tulosyksiköiksi, joita johdetaan toimialaryhmistä käsin, joita johdetaan konsernin johdosta käsin (Tainio ym. 1985). Aikaisemmat vuosikymmenten aikana orgaanisiksi kokonaisuuksiksi kasvaneet yritykset on näin virtaviivaistettu kolmiportaisiksi legotaloiksi, joista yksittäisten palikoiden myyminen ja uusien ostaminen on aikaisempaa huomattavasti kivuttomampi prosessi.

Tämä uudentyyppinen suuryritysten rakenne myös selittää sen ristiriitaiselta näyttävän kehitystendenssin, että pienten yksiköiden ja erilais- ten studioiden merkitys kasvaa (Virtanen 1987) samaan aikaan kun suurkonsernien osuus teollisuuden tuotannosta, viennistä ja tutkimuspanoksesta on edelleen kasvanut (Ahde ym. 1987, 3941).

Ja kuudenneksi: kaiken toiminnan kehittämisen ydinsana on joustavuus, jota voisikin pitää uuden pitkän aallon organisatorisena paradigmana. Joustavuuteen yhdistyy vanhojen, yrityksen toimintaa kahlitsevien rakenteiden purkamisvaatimus (hyvinvointivaltiosta lähtien, puhujasta riippuen) sekä unelma informaatioteknologian avulla markkinoiden muutoksiin nopeasti ja tehokkaasti reagoivasta yrityksestä.

\section{Uusia teollisuusyritystyyppejä}

Kuvattu kehitys merkitsee, että osa teollisuusyrityksistä muuttuu (tai perustetaan) yrityksiksi, joissa tuotteiden fyysinen valmistus on suhteelliselta merkitykseltään hyvin vähäistä tai jopa täysin olematonta. Tällöin lähes kaikki tai kaikki valmistus ostetaan puolestaan pelkästään valmistukseen keskittyneiltä alihankintayrityksiltä, niiltä joilta se kulloinkin edullisimmin saadaan. Tuotantopainotteisten teollisuusyritysten rinnalle on kehittymässä $\mathrm{mm}$. seuraavanlaisia uusia teollisuusyritystyyppejä:

- Tuotekehitysyritys: Yritys keskittyy pelkästään tuotteiden kehittämiseen ja ostaa koko valmistuksen joltakin alihankintatehtaalta ja markkinoinnin joltakin kauppaliikkeeltä. Suomessa on jo lukuisia tällaisia elektroniikkayrityksiä. Myös erilaista suunnittelua tekevät insinööritoimistot kuuluvat tähän kategoriaan.

— Ohjelmistoyritys: Yritys keskittyy pelkästään tuotteiden ohjelmistojen kehittämiseen ja valmistamiseen ja ostaa fyysisen valmistuksen ja markkinoinnin ulkopuolelta.

— Kauppahuoneyritys: Yritys keskittyy tuottei- 
den markkinointiin ja asiakaskohtaisten tuotteiden kehittämiseen ja valmistuttaa tuotteen kokonaan ulkopuolisella alihankkijalla. Monet vaateja huonekaluyritykset ovat kehittymässä tähän suuntaan.

- Kehitysyhtiöt: Yritys keskittyy ostamiensa yritysten johtamiseen (rahoitus, strategia ja kehittäminen) ja myy niitä tarvittaessa pois. Suomessa tällaisia yrityksiä ovat esimerkiksi Sponsor, Finvest, Interpolator ja Mancon.

Tällaisten yritysten rinnalla kasvaa pelkästään erilaisiin palveluihin keskittyvä — ainakin vielä - pienyritysvaltainen yrityspalveluverkosto (joka palvelee muutakin kuin teollisuutta): konsulttitoimistot, ohjelmistotalot, talouslaskenta- ja koulutuspalveluyritykset, mainostoimistot, kauppa- ja agentuuriliikkeet jne.

Aikaisemmin integroituneemmin toiminut teollinen rakenne purkautuu näin hampurilaiseksi, jonka alaleivän muodostavat fyysisten tuotteiden valmistukseen keskittyvät yritykset ja yläleivän yrityspalveluverkosto. Välissä olevan varsinaisen pihvin muodostavat uudet yritystyypit.

Valtaosa menestyvistä teollisista konserneista on muuttumassa tällaisiksi välityypin yrityksiksi. Niiden rinnalle taloutta johtaviksi yrityksiksi tulevat erilaiset kehitysyhtiöt, kauppahuoneet ja suuret ohjelmisto- tai suunnittelutoiminnasta teolliseen valmistukseen sidoksia luovat yritykset. Suomessa tällaisia yrityksiä ovat esimerkiksi Jaakko Pöyry Oy ja Tietotehdas Oy. Tietotehdas Oy on nimensä veroinen: se on Pohjoismaiden suurin ohjelmistotalo, jolla on Suomessa 1200 työntekijää ja Ruotsissa Mods Datema Ab:n oston jälkeen noin 1000 työntekijää.

\section{Informaatio-teollinen kompleksi?}

Uskoakseni edellä kuvatuista trendeistä vallitsee suhteellisen suuri yksimielisyys. Kiistely kohdistuu siihen, miten kokonaiskehitys tulkitaan ja millaisilla nimillä sitä kuvataan.

Tulkintaerimielisyydet johtunevat siitä, ettei nykykehitys näytä nostavan esiin mitään yhtä selväksi kokonaisuudeksi mieltyvăä taloussektoria kuin maatalous ja teollisuus ovat olleet. Loputhan eivät ole palveluita ja jotenkin pitäisi julkinen sektorikin ottaa huomioon. Selkeää informaatiotalouden sektoria ei ole helppo hahmottaa (Aho 1988, 111-118).

Toisaalta tulkintaongelma johtunee siitä, ettei teollisuus ole mihinkään katoamassa (päinvastoin, se uudistuu ja kasvaa "tositeollisuudeksi") (Virtanen 1987) ja että yrityspalveluverkosto kasvaa paljolti teollisuuden sisältä. Näin voidaan aivan oikein sanoa, että vaikka teollisuus välittömästi työllistää tulevaisuudessa vähemmän henkilökuntaa, niin välillisesti se työllistää ehkä jopa enemmän kuin nykyisin (Kavonius 1986).

Eräs tapa ratkaista tulkintaongelma on puhua taloussektoreiden asemesta vain erilaisista työtyypeistä. Esimerkiksi siten, että suoritettava työ surkastuu ja ymmärtävä työ kasvaa samalla kun painopiste siirtyy tehdastyöstä informaatio- ja palvelutyöhön (Kortteinen 1987). Näin varmaan käyneekin (määriteltiin nuo käsitteet ja luokiteltiin erilaiset olemassaolevat työt nyt sitten miten tahansa). Mutta jos ajattelemme kansantalouden toimintaa ja yleistä yhteiskunnallista työnjakoa, erilaisista töistä puhuminen ei auta hahmottamaan nykyisen talouskehityksen dynamoa.

Oma ehdotukseni lähtee tutusta käsitteestä maatalous-teollinen kompleksi, jota on käytetty kuvaamaan sitä miten maatalous on suurelta osin menettänyt itsenäisen roolinsa: maataloudesta on tullut elintarviketeollisuuden (vrt. sopimusviljely ja alihankinta), maatalouskone- ja lannoiteyritysten sekä osuustoiminnallisten kauppa- ja pankkiliikkeiden ohjaamaa toimintaa.

Ehkäpä nyt voitaisiin puhua informaatio-teollisen kompleksin muodostumisesta, jossa tuotantokeskeiset teollisuusyritykset ovat menettämässä suhteellista merkitystään ja itsenäisyyttään. Talouskehityksen johtajan paikalle tulevat erilai- 
set edellä kuvatut uudet yritystyypit.

Näistä käsitemäärityksistä riippumatta on joka tapauksessa selvää, että suurten perinteisten tehdaslaitosten varaan rakentunut ammattiyhdistysliike ja sen mukana koko työväenliike on menettänyt entisen tukevan perustansa. Kansainvälistymisen sivuuttamisen ohella tämä on toinen suuri perinteisten yhteiskunnallisten liikkeiden rakenteellinen heikkous.

\section{LOPUKSI}

Viime aikojen rakennemuutoshuumassa on muistutettu, etteivät muutokset ole välttämättä niin nopeita kuin väitetään (Koistinen 1988, Toivonen 1988). Nopeus onkin aina suhteellinen käsite, mutta kyllä muutokset ovat ainakin niin nopeita, että tieteellisellä tutkimuksella, joka yleensä aina katsoo peruutuspeiliin, on täysi työ pysyä ajan tasalla. Sekä nopea kansainvälistyminen että informaatio-teollisen kompleksin muodostuminen asettavat runsaasti haasteita suomalaiselle yhteiskuntatieteelliselle tutkimukselle.

Informaatio-teollista kompleksia tutkitaan toki Suomessa jo aika paljon - kuten kirjallisuusluettelo osoittaa. Itseäni on alkanut yhä enemmän kiinnostaa ohjelmistotuotanto, koska yleisesti softwaren merkitys kasvaa koko ajan hardwaren kustannuksella ja koska ohjelmistot ovat tulevaisuuden työkaluja, joilla informaation käsittelyn lisäksi valmistetaan vanhoja työkaluja eli koneita, kuljetusvälineitä ja tehtaita ohjaavia informaatiojärjestelmiä. Tällä hetkellä softwaretuotannon tilastointi on aivan retuperällä. VTT:n toimittaman atk-markkinoiden vuosikirjan (Käpyläym. 1988) avullakaan ei pääse kovin pitkälle. Nyt olisi suuri tarve perusteelliselle monitieteelliselle ohjelmistotekniikan, -työn ja -yritystoiminnan tutkimukselle.

Myöskään kansainvälistymisen tutkimus ei ole tilanteen tasalla. Esimerkiksi suomalaisessa työnsosiologisessa tutkimuksessa Antti Kasvion (1985) ansiokas avaus muutaman vuoden takaa on saanut hämmästyttävän vähän jatkoa. Meillä tehdään kyllä jo hyvää vertailevaa kansainvälistä tutkimusta (esim. Luokkaprojekti 1984 jatkoineen, Kosonen 1987). Mutta nyt olisi edettävä eri maiden vertailusta maiden välisten suhteiden ja vaikutusmuotojen analysointiin. 


\section{Kirjallisuus}

Aho, S.:Palkkatyö yhteiskunnallisen järjestyksen perustana. Jyväskylä 1988.

Ahde, P., Karko, J., Vuori, S., Ylä-Anttila, P.: Teollisuuden rakennemuutos. Julkaisussa Suhdanne 1987/4. Elinkeinoelämän tutkimuslaitos. Helsinki 1987.

Aivojen miljöö. Fakta 11/87.

Allardt, E.: Sociologin och världsamhället. Sosiologia 4/1987.

Insinööriuutiset 3.2.1988, 29.2.1988.

Julkunen, R.: Työprosessi ja pitkät aallot. Työn uusien organisaatiomuotojen synty ja yleistyminen. Jyväskylä 1987.

Kasvio, A.: Teollisen tuotannon kansainvälistyminen ja uusi kansainvälinen työnjako. $Y \boldsymbol{h}$ teiskuntatieteiden tutkimuslaitos, Tampereen yliopisto. Sarja D 75. Tampere 1985.

Kavonius, M.: Millaiseen yhteiskuntaan? Kirjassa Tietoyhteiskunta meissä. Liikenneministeriö. Helsinki 1986.

Kevätsalo, K.: Mahdollisuuksia ja uhkia. Metallityöläiset ja tietotekniikan käyttöönotto. Metallityöväen Liitto ry. Tampere 1987.

Kivinen, M: Parempien piirien ihmisiä-näkökulma uusiin keskiluokkiin. Jyväskylä 1987.

Koistinen, P.: Työelämän murros ja yhteiskuntatieteiden tulkinnat. Käsikirjoitus 3.2.1988.

Kortteinen, M.: Hallittu rakennemuutos? Helsinki 1987.

Kosonen, P.: Hyvinvointivaltion haasteet ja pohjoismaiset mallit. Mänttä 1987.

Kuusi, J.: Eurooppalainen teknologiayhteistyö Suomen elinkeinoelämän kannalta. PTT Katsaus 4/1987a.

Kuusi, J.: Teknologian kehityksen ja kehittämisen suuntaviivoista. Julkaisussa Tiede- ja teknologiapoliittinen katsaus 1987 . Valtion tiede- ja teknologianeuvosto. Helsinki 1987b.

Kuusi, O.: Tietoyhteiskunnan alueellinen eteneminen Suomessa. Kirjassa Tietoyhteiskunta meissä. Helsinki 1986.
Käpylä, T. ym.: Suomen ATK-markkinoiden vuosikirja 1987. VTT/Atk-palvelutoimisto. Otaniemi 1988.

Lovio, R.: Teollisuuden murros OECD-maissa. Tiede \& edistys 1/1985.

Lovio, R. \& Lemola, T.: Suomen teollisuuden uudistuminen ja teknologinen taso. STIUprojektin työpapereita 2 . VTT/SUM. Otaniemi 1986.

Lovio, R.: 21 innovaatiota Suomen elektroniikkateollisuudessa - taustaa, menestystekijöitä, ongelmia. STIU-projektin työpapereita 4. VTT/SUM. Otaniemi 1988.

Luokkaprojekti: Suomalaiset luokkakuvassa. Jyväskylä 1984.

Luostarinen, R.: Kansainvälistyminen - yritysten keskeinen strategia 1980-luvulla. Helsinki 1980.

Räsänen, K.: Suomalaisten suuryritysten viimeaikainen kehitys. Esitelmä Kansantaloustieteen päivillä Turussa 18-19.2.1988.

Tainio, R., Räsänen, K. \& Santalainen, T.: Suuryritykset ja niiden johtaminen Suomessa. Tampere 1985.

Talouselämä 25/87, 1/88, 4/88.

Teollisuuden Keskusliitto: Teollisuuden rakennemuutos. Keskustelumuistio 15. Helsinki 1987.

Toikka, K., Hyötyläinen, R. \& Norros, L.: Työn kehitys joustavassa valmistuksessa. Aikuiskasvatus 4/1985.

Toivonen, T.: 1980-luvun rakennemuutos on oletettua pienempi. Insinööriuutiset 8.2.1988.

Virtanen, M.: Tehtaasta studioon. Helsinki 1987.

Vuorinen, P.: Joustava tuotantoautomaatio ja teollisuuden uusi tuotantomuoto. TES-ohjelman keskustelualoitteita 1. Sitra. Helsinki 1987. 